\title{
Investigation of an interleukin-4 promoter polymorphism for associations with asthma and atopy
}

\author{
A J Walley, W O C M Cookson
}

\begin{abstract}
The cytokine cluster located on chromosome 5 has been shown by linkage studies to play a role in the genetic determination of circulating immunoglobulin $\mathrm{E}$ (IgE) levels in atopic subjects. In the study presented here, the reported chromosome 5 linkage has been investigated in two sets of subjects. The first consisted of a general population sample of 230 nuclear families ( $n=1004$ ) from Busselton, a small West Australian country town. The second group consisted of 124 unrelated atopic asthmatics and 59 unrelated non-atopic, non-asthmatic controls, all resident in the Oxfordshire Regional Health Authority area in the United Kingdom. A previously reported interleukin-4 (II-4) promoter polymorphism $(-590 \mathrm{C} \rightarrow \mathrm{T})$ was analysed in these populations by a newly designed method of specific PCR amplification and BsmFI restriction endonuclease digestion. In the Busselton population the polymorphism was shown to be weakly associated with specific IgE to house dust mite (Mann-Whitney-U test, $p=0.013$ ) and to wheeze (MWU test, $p=0.029$ ), but not with specific IgE to grass pollen, total serum IgE, bronchial hyperresponsiveness, eosinophil count, or asthma. In the Oxfordshire subjects there were no statistically significant associations with any measure of asthma or atopy. These data show that the $-590 \mathrm{C} \rightarrow \mathrm{T}$ Il-4 promoter polymorphism is only weakly associated with certain measures of asthma and atopy in some subjects. It was specifically not associated with serum IgE concentration or asthma in either of the two groups in this study.
\end{abstract}

(F Med Genet 1996;33:689-692)

Key words: interleukin-4; asthma; atopy.

The response of the immune system to allergens is governed by a large range of factors, both environmental and genetic. There is ample evidence that environmental factors influence the development of allergic diseases such as asthma, eczema, and hay fever ${ }^{1}$ (collectively known as atopy) and there is now evidence that genetic factors are important as well. ${ }^{1-3}$ Asthma, eczema, and hay fever involve chronic inflammation of the airways, the skin, and the nasal mucous membranes. These three conditions may be seen alone, or together in the same patient. They lead to substantial losses in working hours and significant morbidity and mortality.

The IgE mediated mechanism which results in an inflammatory response is important in neutralising invading pathogens, typically extracellular parasites such as hookworm (Ancylostoma duodenale) or the blood fluke (Schistosoma mansoni).${ }^{4}$ In atopy, the same mechanism is triggered by ubiquitous allergens, such as the faeces of the house dust mite, cat and dog dander, and grass pollen.

The allergic response begins with the allergen being bound by specific IgE, the latter already being bound to the high affinity $\operatorname{IgE}$ receptor (FceRI) on mast cells and basophils. Cross linking of the immunoglobulin receptor complex on the cell surface leads to a signalling cascade involving phospholipase $\mathrm{C}$ and protein kinase $\mathrm{C}$ pathways. The cascade triggers an acute response in which histamine, prostaglan$\operatorname{din} \mathrm{D}_{2}$, platelet activating factor, interleukin- 4 (Il-4), and other cytokines are released from cytoplasmic granules. Il-4 activates the pre-T helper cells ${ }^{5}$ so that they become $\mathrm{T}_{\mathrm{h}} 2$ cells. $^{6}{ }^{7}$ These cells then trigger isotype switching in $\mathrm{B}$ cells from IgG/IgM to IgE, subsequently enhancing the degranulation of mast cells by increasing the saturation of $F c \in R I$ receptors with allergen/IgE complexes.

In the absence of continued allergen challenge, the inflammatory response is reduced to basal level by cytokines that switch $\mathrm{T}_{\mathrm{h}} 2$ cells to the $T_{h} 1$ phenotype. These cytokines include interleukin-12, transforming growth factor beta, and interferon gamma. ${ }^{8}$ The heterogeneity of atopy has been explained by differing levels in cytokines between atopic and non-atopic subjects. ${ }^{9}{ }^{10}$ However, it should be noted that at least one study has found no correlation between Il-4 expression and serum IgE levels in atopic subjects. ${ }^{11}$

Genetic markers within and around 5q31-33 have been shown to be linked to total serum IgE concentration in the $\mathrm{USA}^{12}$ and Holland. ${ }^{13}{ }^{14}$ They have provided strong evidence that there are one or more loci in 5q31-33 that are closely involved in raised serum IgE levels and bronchial hyperresponsiveness. The gene encoding interleukin- 4 is within this region and is therefore a possible candidate for the reported genetic linkage.

An SSCP Il-4 marker had previously been linked to asthma, ${ }^{15}$ when three different interleukins were analysed for promoter polymorphisms. This interleukin- 4 promoter polymorphism was found to be present at high fre- 
quency in asthmatics $(35 / 95=0.37)$. It was also associated with a raised serum IgE concentration. The polymorphism is a $\mathrm{C}$ to $\mathrm{T}$ change at position -590 counting from the first ATG codon. ${ }^{16}$ The polymorphism is upstream of all the previously described control elements of interleukin- $4^{17-21}$ as shown in fig 1. It may nevertheless form part of a previously undescribed element, because it has been shown that regions as far upstream as -3000 are required for full wild type expression levels. ${ }^{21}$ Recently, Rosenwasser ${ }^{22}$ has reported binding of nuclear factors to this region, and has shown enhanced activity for the variant promoter when placed in a luciferase reporter gene expression construct.

To assess the possible role of this Il-4 polymorphism in modulating the allergic response, 230 nuclear families were taken from a general Australian population who have been studied in detail for measures of asthma and atopy. To test further whether the polymorphism influences asthma, a set of children with asthma and a set of normal controls were taken from a UK population.

\section{Methods}

SUBJECTS

The first group was obtained from the town of Busselton, West Australia, and consisted of 1004 people from 230 nuclear families, as described previously. ${ }^{23}$ The second group consisted of 124 unrelated atopic asthmatics and 59 unrelated non-atopic, non-asthmatics all resident in the Oxfordshire Regional Health Authority area in the United Kingdom. Atopic, asthmatic probands under the age of 21 were identified through hospital outpatient clinics or through general practitioners' surgeries. The controls were normal sibs of probands from the same subject group but from different families.
CLINICAL PARAMETER MEASUREMENT

All subjects were asked to complete a questionnaire, based upon the American Thoracic Society questionnaire, but including questions on allergies and rhinitis. In both sets of subjects, "asthma" was a positive answer to the questions: "Have you ever had an attack of asthma?" and "If yes, has this happened on more than one occasion?". "Wheeze" was defined as a positive answer to the questions: "Has your chest ever sounded wheezy or whistling?" and "If yes, has this happened on more than one occasion?". In Oxfordshire, the asthma was also clinically diagnosed. Bronchial responsiveness to methacholine challenge was measured in the Busselton subjects only (maximum dose $12 \mu \mathrm{mol}$ ) and the dose required to provoke a $20 \%$ fall in forced expiratory volume in one second $\left(\mathrm{PD}_{20}\right)$ was calculated by linear interpolation. Subjects in whom a $20 \%$ fall was not achieved by the maximum dose of methacholine were assigned an arbitrary $\mathrm{PD}_{20}$ of 100 . Bronchial hyperresponsiveness (BHR) was defined as $\mathrm{PD}_{20}$ less than or equal to $8 \mu \mathrm{mol}$ of methacholine. ${ }^{24}$ Atopy was defined as a positive skin test to house dust mite (Dermatophagoides pteronyssinus) or timothy grass (Phleum pratense) greater than $4 \mathrm{~mm}$ greater than a negative control. Total serum IgE and specific IgE responses to whole house dust mite and timothy grass were determined using the Pharmacia CAP system (Pharmacia Biotech, Uppsala, Sweden), which is a fluorescent enzyme immunoassay system (FEIA). This system gives equivalent values for IgE to the older radioallergosorbent test (RAST). The peripheral blood eosinophil count was counted automatically (Western Diagnostic Laboratories, Western Australia and Haematology Department, John Radcliffe Hospital, Oxford).

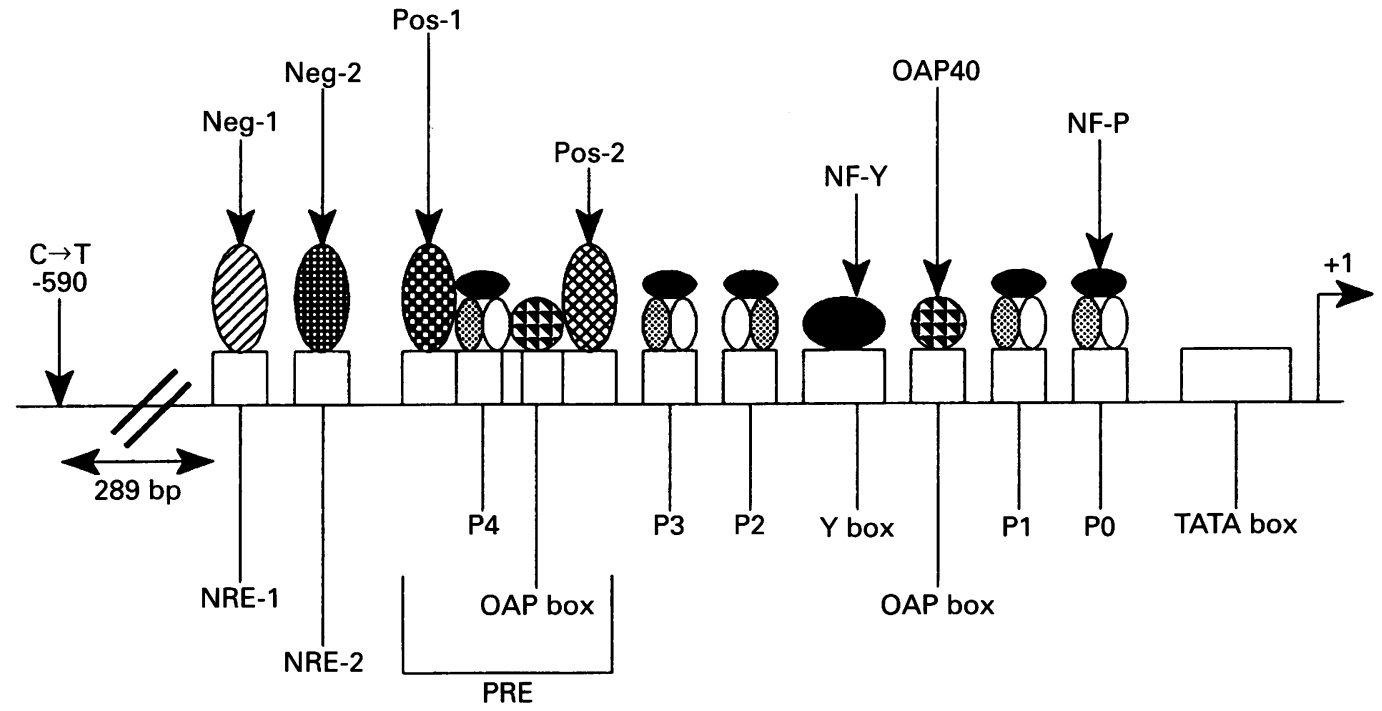

Figure 1 Diagrammatic representation of known control elements within the Il-4 promoter with respect to the $-590 C \rightarrow T$ polymorphism. NRE-1 = Negative Regulatory Element 1, NRE-2 = Negative Regulatory Element 2, Neg1 = Nuclear factor that suppresses Il-4 transcription, Neg2 = Second nuclear factor that suppresses Il-4 transcription, PRE = Positive Regulatory Element, NF-P $=$ Nuclear Factor $P, N F-Y=$ Nuclear Factor $Y, Y$ Box $=N F-Y$ recognition sequence, $P 0, P 1$, $P 2, P 3, P 4=N F-P$ recognition sequences, $O A P 40=O c t-1$ associated protein, $O A P$ box $=O A P 40$ recognition sequence, TATA = Transcription initiation signal. The numbers are based upon the +1 being the first nucleotide of the first codon of the interleukin-4 protein. NF-P was thought to be a complex of Nuclear Factor of Activated T cells (NF-ATc) bound to a c-Fos-c-fun heterodimer but there is some evidence that NF-ATc alone is sufficient for activity. P2 is shown in italics because the sequence is in the reverse orientation compared to the other four P elements. The P4 element and the upstream $O A P$ box overlap. 
Table 1 Phenotypic data and frequency of $-590 C \rightarrow T$ in Busselton families and Oxfordshire cases and controls

\begin{tabular}{llllllllll}
\hline & & & & & & & \multicolumn{2}{c}{ Frequency of $-590 C \rightarrow T$} \\
\cline { 6 - 10 } & Mean age (SD) & $\begin{array}{l}\text { Males } \\
\text { (\%) }\end{array}$ & $\begin{array}{l}\text { Atopy } \\
(\%)\end{array}$ & $\begin{array}{l}\text { Asthma } \\
(\%)\end{array}$ & $\begin{array}{l}\text { BHR } \\
\text { (\%) }\end{array}$ & All & Asthma & Normal \\
\hline Busselton families & $25.2(0.46)$ & 50 & 35 & 21 & 20 & 0.27 & 0.30 & 0.26 \\
Oxon cases and controls & $13.5(0.38)$ & 57 & 58 & 68 & ND & 0.31 & 0.33 & 0.27 \\
\hline
\end{tabular}

^ Bronchial hyperresponsiveness was defined as a $\mathrm{PD}_{20}$ to methacholine less than or equal to $8 \mu \mathrm{mol}$ of methacholine. ${ }^{24} \mathrm{ND}$ means not determined for this subject group.

GENOMIC DNA ISOLATION

Genomic DNA from each subject was isolated from a $10-50 \mathrm{ml}$ whole blood sample by phenol/chloroform extraction and ethanol precipitation using a modified version of the method of Blin and Stafford. ${ }^{25}$

PCR AMPLIFICATION OF THE REGION CONTAINING THE IL-4 PROMOTER POLYMORPHISM

To 50-200 ng of genomic DNA was added: 1.5 $\mu 110 \times$ reaction buffer (Boehringer Mannheim $\mathrm{GmbH}$, Germany), $1.5 \mu \mathrm{l} 10 \times \mathrm{dNTP}$ mixture ( $5 \mathrm{mmol} / 1 \mathrm{dATP}$, dCTP, dGTP, dTTP), $1.5 \mu \mathrm{l}$ $5^{\prime}$ primer $(50 \mathrm{ng} / \mathrm{ml}), 1.5 \mu \mathrm{l} 3^{\prime}$ primer $(50$ $\mathrm{ng} / \mathrm{ml}$ ), $0.5 \mu \mathrm{l} \mathrm{Taq}$ DNA polymerase (0.6 units, Boehringer Mannheim), and sterile water to a final volume of $15 \mu \mathrm{l}$. The region of interest was then amplified using the polymerase chain reaction $(P C R)^{26}$ in a Perkin Elmer Cetus 480 DNA thermal cycler. The PCR conditions were five minutes at $94^{\circ} \mathrm{C}$ followed by 32 cycles of 30 seconds at $94^{\circ} \mathrm{C}, 57^{\circ} \mathrm{C}$, and $72^{\circ} \mathrm{C}$ and a final five minutes at $72^{\circ} \mathrm{C}$. The PCR primers were as follows: $5^{\prime}$ primer (AW41A) 5'-ACTAGGCCTCACCTGATACG-3', 3' primer (AW41B) 5'-GTTGTAATGCAGTCCTCCTG-3'. This resulted in a PCR product of 252 bp spanning positions 522 to 774 in the interleukin-4 promoter sequence (GenBank accession number M23442).

RESTRICTION ENZYME DIGESTION OF PCR AMPLIFIED DNA

A total of $5 \mu \mathrm{l}$ of PCR product was added to 3.5 $\mu \mathrm{l}$ sterile water together with $1 \mu \mathrm{l}$ of NEBuffer 4 and $0.5 \mu \mathrm{l}$ of BsmFI (1 unit) (New England

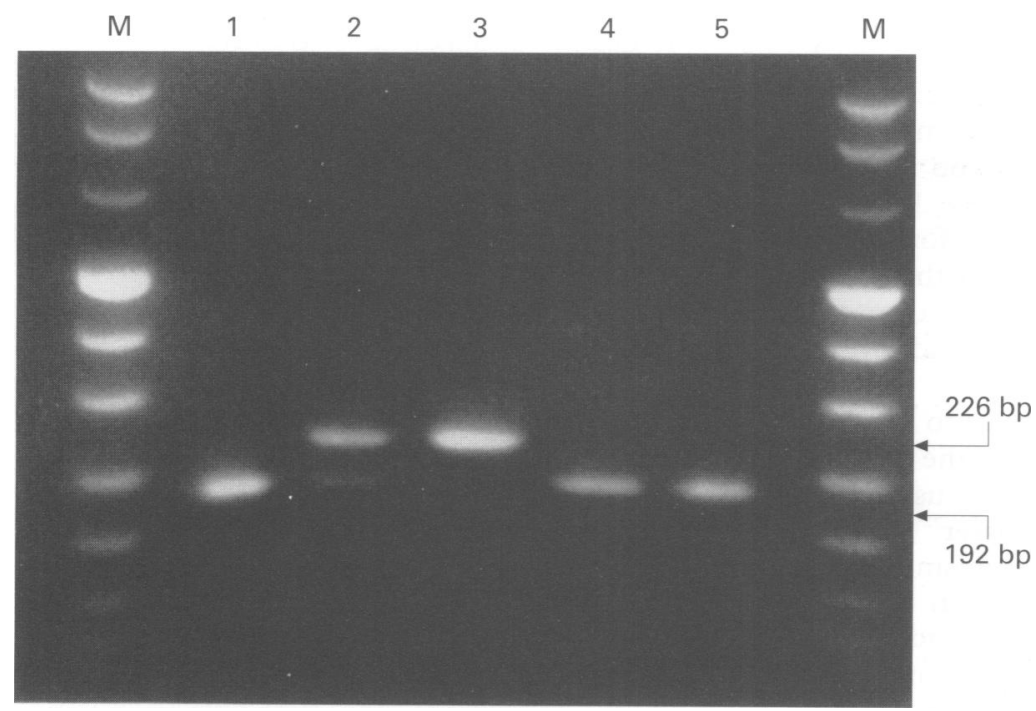

Figure 2 BsmFI restriction endonuclease digestion of $P C R$ products amplified from nucleotide 522 to nucleotide 744 of the Il-4 gene sequence (GenBank accession number M23442) in five unrelated subjects. $M=D N A$ molecular weight markers (Boehringer Mannheim Marker VIII), 1, 4, and $5=$ homozygote for the wild type allele, $2=$ heterozygote for the wild type allele and the $-590 \mathrm{C} \rightarrow T$ allele, $3=$ homozygote for the -590
$C \rightarrow T$ allele.
Biolabs) to give a final volume of $10 \mu \mathrm{l}$. The restriction digest mixture was then incubated at $37^{\circ} \mathrm{C}$ for one hour. The reaction was stopped by the addition of $5 \mu$ l of agarose gel loading buffer $(5 \times \mathrm{TBE}, 0.5 \mathrm{~mol} / 1 \mathrm{EDTA}$, $10 \%(\mathrm{v} / \mathrm{v})$ glycerol, $0.05 \%(\mathrm{w} / \mathrm{v})$ Bromophenol Blue). The restriction digest was carried out at $37^{\circ} \mathrm{C}$ rather than at the optimum temperature for BsmFI activity, $65^{\circ} \mathrm{C}$, because of undesirable Taq DNA polymerase activity at this temperature. At $37^{\circ} \mathrm{C}$ the restriction enzyme retained $50 \%$ of its activity.

\section{AGAROSE GEL ELECTROPHORESIS OF DNA} FRAGMENTS

All $15 \mu \mathrm{l}$ of the restriction digest mixture was then loaded onto a $2 \%(\mathrm{w} / \mathrm{v})$ agarose $/ 1 \times \mathrm{TBE}$ gel, containing $50 \mathrm{ng} / \mathrm{ml}$ ethidium bromide, in a BioRad wide Mini-Sub cell and electrophoresed at $70 \mathrm{~V}$ for 90 minutes. DNA molecular weight markers were also loaded on the gel for reference (Boehringer Mannheim Marker VIII). Fragments of DNA were then visualised by UV transillumination and photographed using a Stratagene video image capture system and thermal printer.

\section{STATISTICAL ANALYSIS OF DATA}

Non-parametric analysis of the data was carried out using the SPSS software package (SPSS Inc, USA) to produce MannWhitney-U Wilcoxon rank sum test and relative risk results.

\section{Results}

Cleavage by $B s m F I$ of the 252 bp full length Il-4 PCR product results in two fragments of $192 \mathrm{bp}$ and $60 \mathrm{bp}$. The $-590 \mathrm{C} \rightarrow \mathrm{T}$ polymorphism abolishes this site. Fig 2 illustrates this with examples of a homozygote for the wild type allele in lane 1, a heterozygote in lane 2, and a homozygote for the $-590 \mathrm{C} \rightarrow \mathrm{T}$ allele in lane 3. Lanes 4 and 5 are homozygotes for the wild type allele. Under these electrophoresis conditions the $60 \mathrm{bp}$ cleavage product is not visible.

There was no significant difference in polymorphism frequency between the Busselton and Oxfordshire non-asthmatic subjects (table 1). The Oxfordshire asthmatics had a slightly higher frequency of 0.33 than the nonasthmatic, non-atopic controls, but this was lower than the previously reported value of 0.37 in white American asthmatics. ${ }^{15}$

Table 2 shows the statistical analysis of the results for the two populations. The only statistically significant results from the MannWhitney-U test are in the Busselton population between the promoter polymorphism and the specific IgE to house dust mite $(p=0.013)$ and 
Table 2 Mann-Whitney-U Wilcoxon rank sum test analysis of associations between the $-590 \mathrm{C} \rightarrow T$ interleukin-4 promoter polymorphism and phenotypic traits related to atopy and asthma. Bronchial hyperresponsiveness (BHR) was not measured in the Oxfordshire subjects

\begin{tabular}{lll}
\hline & \multicolumn{2}{l}{ Subject group } \\
\cline { 2 - 3 } & $\begin{array}{l}\text { Busselton } \\
(n=1004)\end{array}$ & $\begin{array}{l}\text { Oxfordshire } \\
(n=183)\end{array}$ \\
\hline Phenotypic trait & 0.985 & 0.895 \\
Log $_{\mathrm{e}}$ (total IgE) & $\mathbf{0 . 0 1 3}$ & 0.368 \\
Specific IgE-dust & 0.949 & 0.769 \\
Specific IgE-grass & 0.432 & 0.638 \\
Eosinophil count & 0.352 & $\mathrm{NA}$ \\
BHR & 0.397 & 0.424 \\
Asthma symptoms & $\mathbf{0 . 0 2 9}$ & 0.750 \\
Wheeze & & \\
\hline
\end{tabular}

Table 3 Relative risks associated with inheriting the - 590 C $\rightarrow T$ interleukin-4 promoter polymorphism and asthma or wheeze

\begin{tabular}{lll}
\hline & $\begin{array}{l}\text { Relative risk of asthma } \\
\text { (95\% confidence } \\
\text { intervals) }\end{array}$ & $\begin{array}{l}\text { Relative risk of wheeze } \\
\text { (95\% confidence } \\
\text { intervals) }\end{array}$ \\
\hline Subject group & $1.146(0.836-1.571)$ & $1.329(1.029-1.718)$ \\
Ousselton & $1.282(0.697-2.355)$ & $1.109(0.587-2.094)$ \\
\hline
\end{tabular}

to the clinical symptom of wheeze $(p=0.029)$. None of the traits analysed in the Oxfordshire subjects were significantly associated with the polymorphism.

Table 3 shows the calculated relative risk of having asthma or wheeze in subjects with the $-590 \mathrm{C} \rightarrow \mathrm{T}$ polymorphism. Only the relative risk for wheeze was significant in the Busselton population with a value of 1.33 and $95 \%$ confidence intervals of 1.03-1.72. There was no relationship of the polymorphism to asthma in either of the populations.

\section{Discussion}

These results show that the Il-4 promoter polymorphism is found at a population prevalence of $0.26-0.27$ in the two study groups. The slightly increased frequency in the Oxfordshire asthmatics (0.33) is not significantly different from the non-asthmatic controls. The similar population prevalences of the promoter polymorphism between the Busselton and Oxford populations contrasts with the finding of statistically significant associations in the former and not the latter. This may be because of the lower levels of atopy and asthma in the Busselton subject group (table 1) showing an effect that is masked in the Oxfordshire group. It is also likely that although the two subject groups are genetically close, the disparate environments of the two groups could explain these differences.

Interleukin-4 is central to the allergic response and the findings of the present study differ from those of the previous report of the polymorphism. ${ }^{15}$ Rosenwasser ${ }^{22}$ has recently reported that this polymorphism is involved in regulating promoter activity in vitro, but the present study provides little evidence that the polymorphism is associated with asthma or atopy in vivo. However, other polymorphisms in interleukin- 4 may be functionally important in the subjects studied. It seems increasingly possible that, although interleukin- 4 is an ideal candidate gene for atopy and asthma, it is not responsible for the reported linkages to the chromosome 5q31-33 region.

The authors wish to acknowledge the work of Drs A W Musk and P Le Söuef in Australia and Mrs A Shaw in Oxford for the coordination and collection of blood samples, Dr J Faux for the FEIA data, Drs M R Hill and M F Moffatt for valuable help and advice, and, finally, all the subjects who contributed the samples and time that made this study possible. This research was funded by the Wellcome Trust. Dr W O C M Cookson is a Senior Wellcome Research Fellow.

1 Marsh DG, Meyers DA, Bias WB. The epidemiology and genetics of atopic allergy. $N$ Engl $f$ Med 1981;305:1551-9.

Cookson WOCM, Sharp PA, Faux JA, et al. Linkage

between immunoglobulin $\mathrm{E}$ responses underlying asthma and rhinitis and chromosome 11q. Lancet 1989;i:1292-5.

3 Moffatt MF, Hill MR, Cornélis F, et al. Genetic linkage of T-cell receptor $\alpha / \delta$ complex to specific IgE responses. Lancet 1994;343:1597-600.

4 Maizels RM, Bundy DAP, Selkirk ME, et al. Immunological modulation and evasion by helminth parasites in human populations. Nature 1993;365:797-805.

5 Ricci M. Il-4: a key cytokine in atopy. Clin Exp Allergy 1994; 24:801-12

6 Mosmann TR, Cherwinski H, Bond MW, et al. Two types of murine helper $\mathrm{T}$ cell clone. I. Definition according to profiles of lymphokine activities and secreted proteins. $f$ Immunol 1986;136:2348-57.

7 Kelso A. Th1 and Th2 subsets: paradigms lost? Immunol Today 1995;16:374-9.

8 Barnes P. Cytokines as mediators of chronic asthma. $A m \mathcal{F}$ Respir Crit Care Med 1994;150:S42-9.

9 Pène J. Heterogeneity of atopy demonstrated by differences in cytokine release by peripheral blood T cells. Ann Allergy 1993;71:322-6.

10 Pène J, Rivier A, Lagier B, et al. Differences in Il-4 release by $\mathrm{PBMC}$ are related with heterogeneity of atopy. Immunology 1994;81:58-64

11 Van der Pouw-Kraan CTM, Aalberse RC, Aarden LA. IgE production in atopic patients is not related to Il-4 production. Clin Exp Immunol 1994:97:254-9.

12 Marsh DG, Neely JD, Breazeale DR, et al. Linkage analysis of Il4 and other chromosome 5q31.1 markers and total serum immunoglobulin E concentrations. Science 1994; 264:1152-6.

13 Postma DS, Bleecker ER, Amelung PJ, et al. Genetic susceptibility to asthma - bronchial hyperresponsiveness coinherited with a major gene for atopy. $N \mathrm{Engl} \mathcal{F} \mathrm{Med}$ 1995;333:894-900

$14 \mathrm{Xu}$ J, Levitt RC, Panhuysen CIM, et al. Evidence for two unlinked loci regulating total serum IgE levels. Am $\mathcal{F}$ Hum Genet 1995;57:425-30.

15 Borish L, Mascali JJ, Klinnert M, et al. SSCP polymorphisms in interleukin genes. Hum Mol Genet 1994;3:1710.

6 Arai N, Nomura D, Villaret D, et al. Complete nucleotide sequence of the chromosomal gene for human Il-4 and its expression. F Immunol 1989;142:274-82.

17 Abe E, Malefyt RDW, Matsuda I, et al. An 11-base-pair DNA sequence motif apparently unique to the human interleukin-4 gene confers responsiveness to T-cell activainterleukin-4 gene confers responsiveness to T-cell act

18 Chuvpilo S, Schomberg C, Gerwig R, et al. Multiple closely-linked NFAT/octamer and HMG I(Y) binding closely-linked NFAT/octamer and HMG I(Y) binding
sites are part of the interleukin-4 promoter. Nucleic Acids sites are part of the int
Res 1993:21:5694-704.

19 Li-Weber L, Krafft H, Krammer PH. A novel enhancer in the human Il-4 promoter is suppressed by a positionindependent silencer. $\mathcal{F}$ Immunol 1993;151:1371-82.

20 Szabo SJ, Gold JS, Murphy TL, et al. Identification of cis-acting regulatory elements controlling interleukin-4 gene expression in T cells: roles for NF-Y and $\mathrm{At}_{c}$. Mol Cell Biol 1993;13:4793-805.

21 Todd MD, Grusby MJ, Lederer JA, et al. Transcription of the interleukin- 4 gene is regulated by multiple promoter the interleukin-4 gene is regulated by muth

22 Rosenwasser LJ. Human Il-4 gene promoter polymorphisms in atopic asthma. Genetics of Asthma Conference, Broadway, in atopic asthma. Genetics of $A$.

23 Hill MR, James AL, Faux JA, et al. FceRI- $\beta$ polymorphism and risk of atopy in a general population sample. $B M \mathcal{F}$ 1995;311:776-9.

24 Peat JK, Salome CM, Bauman A, et al. Repeatability of histamine bronchial challenge and comparability with methacholine bronchial challenge in a population of Australian schoolchildren. Am Rev Respir Dis 1991;144:336-43.

25 Blin N, Stafford DW. A general method for isolation of high molecular weight DNA from eukaryotes. Nucleic Acids Res 1976;3:2303.

26 Sakai RK, Gelford DH, Stoeffel S, et al. Primer-directed enzymatic amplification of DNA with a thermostable DNA polymerase. Science 1988;239:487-91. 